\title{
Sodium monensin or propolis extract in the diet of Nellore bulls finished in feedlot: chemical composition and fatty acid profile of Longissimus muscle
}

\section{Monensina sódica ou extrato de própolis na dieta de bovinos Nelore terminados em confinamento: composição química e perfil de ácidos graxos do músculo Longissimus}

\author{
Fernando Zawadzki ${ }^{1}$; Ivanor Nunes do Prado ${ }^{2 *}$; Jair de Araújo Marques ${ }^{3}$; Lúcia \\ Maria Zeoula ${ }^{4}$; Rodolpho Martin do Prado ${ }^{5}$; Carlos Alberto Fugita ; Maribel \\ Velandia Valero ${ }^{5}$; Daniele Maggioni ${ }^{5}$
}

\begin{abstract}
This work was carried out to evaluate the chemical composition and fatty acid profile of Longissimus muscle of 33 Nellore bulls with 27 months old and initial average weight of $402 \pm 7.58 \mathrm{~kg}$ finished in feedlot. Three treatments (Control - CON, Monensin - MON and Propolis extract - PRO) were evaluated. The animals were kept in feedlot during 84 days and slaughtered with final average weight with $488 \pm$ $24.9 \mathrm{~kg}$. The addition of additives (monensin or propolis extract) did not influence $(\mathrm{P}>0.10)$ the chemical composition of Longissimus muscle of bulls. Saturated fatty acid (SFA) did not have difference $(\mathrm{P}>0.10)$ among treatments. Monounsaturated fatty acids (MUFA) have difference $(\mathrm{P}<0.01)$ among treatments. The highest value was observed in CON treatment $(47.0 \%)$. There is also difference $(\mathrm{P}<0.01)$ among treatments for polyunsaturated fatty acids (PUFA). Bulls of MON $(9.92 \%)$ treatment obtained highest $(\mathrm{P}<$ $0.01)$ value for PUFA. Bulls of CON (6.74\%) and PRO (6.93\%) have lowest $(\mathrm{P}<0.01)$ values for PUFA.
\end{abstract} Key words: Additives, CLA, cholesterol, meat quality, ruminant

\section{Resumo}

Este trabalho foi realizado para avaliar a composição química e a composição de ácidos graxos do músculo Longissimus de 33 machos não castrados da raça Nelore com 27 meses de idade e peso médio inicial de $402 \pm 7.58 \mathrm{~kg}$ terminados em confinamento. Foram usados três tratamentos: Controle $-\mathrm{CON}$, Monensina - MON e Extrato de Própolis - PRO. Os bovinos foram mantidos confinados durante 84 dias e abatidos com peso vivo médio final de $488 \pm 24.9 \mathrm{~kg}$. A adição dos aditivos (monensina ou extrato de própolis) não tiveram influência $(\mathrm{P}>0,10)$ na composição química do músculo Longissimus dos bovinos. A composição de ácidos graxos saturados (AGS) foi semelhante entre os tratamentos (P $>0,10)$. A composição de ácidos graxos monoinsaturados foi diferente entre os tratamentos $(\mathrm{P}<0,01)$. Valor superior foi observado nos bovinos da dieta CON (47,0\%). Da mesma forma, houve diferença (P

\footnotetext{
1 Post-Graduate student. Department of Animal Science. State University of Maringá, UEM. E-mail: fernandozawadzki@hotmail. com

2 Ph D Prof., Department of Animal Science. State University of Maringa, UEM. Av. Colombo, 5790, CEP 87020-900, Maringá, Paraná, Brazil. E-mail: inprado@uem.br

3 Prof., Department of Animal Science. Federal University of Recôncavo of Bahia, Brazil. E-mail: jdmarques@hotmail.com

4 Ph D Prof., Department of Animal Science. State University of Maringa, UEM. E-mail: lmzeoula@uem.br

5 Post-Graduate student, Department of Animal Science. State University of Maringá, UEM. E-mail: rodophoprado@hotmail. com; betofugita@yahoo.com.br; maribelvelandia@hotmail.com; danielemaggioni@hotmail.com

*Corresponding author
} 
$<0,01)$ entre tratamentos para os ácidos graxos poliinsaturados (AGPI). Bovinos do tratamento $(9,92 \%)$ apresentaram maior $(\mathrm{P}<0,01)$ valor para os AGPI. Os bovinos dos tratamentos $\mathrm{CON}(6,74 \%)$ e PRO $(6,93 \%)$ apresentaram menores valores $(\mathrm{P}<0,01)$ para os AGPI.

Palavras-chave: Aditivos, CLA, colesterol, qualidade da carne, ruminantes

\section{Introduction}

The meat has important nutritional function on human diet by proteins with high quality (WEBB; O'NEIL, 2008), essential fatty acids (MOREIRA et al., 2003; KAZAMA et al., 2008; MACEDO et al., 2008; DUCATTI et al., 2009; MAGGIONI et al., 2009; ROTTA et al., 2009a; 2009b), minerals and complex B vitamins. However, the consumption of red meat has been associated with health problems (cardio diseases, obesity, hypertension and cancers, WOOD et al., 2004) by presence of saturated fatty acids and cholesterol (KAZAMA et al., 2008; PRADO et al., $2009 a ; 2009 b ; 2009 c)$. The presence of saturated fatty acid in meat is related to the biohydrogenation process in the rumen (TAMMINGA; DOREAU, 1991).

To increase the animal production is necessary to develop new process and technologies. Additives (ionophores) are used in ruminant feed with a purpose to improve the alimentary efficiency (OLIVEIRA et al., 2006). The sodium monensin has been used in ruminant diets. Sodium monensin act in gram-positives bacteria by alteration on flux of ions in cellular membrane to select the gram-negatives bacteria (DUFFIELD; BAGG, 2000). Ruminal micro flora is modified to alter the production of volatile fatty acids which ultimately improve the animal performance and the alimentary conversion (OLIVEIRA et al., 2006). In Europe the inclusion of sodium monensin is prohibited. The resolution EU 1831/2003 prohibits the use of sodium monensin since January of 2006. Thus, new researches are necessary for the development of alternative products to diets of ruminants.

Propolis has been demonstrated several bioactivities with eminence to anti-bacteria action that is related to the flavonoids (MARCUCCI, 1995). However, researches using propolis extract on meat quality in cattle are not found in literature.
This work was carried out to study the chemical composition and the fatty acid profile of Longissimus muscle of Nellore bulls finished in feedlot and fed with sodium monensin or propolis extract.

\section{Material and Methods}

\section{Animal management and sampling}

The committee of Animal Production at the State University of Maringá approved this study (CIOMS/ OMS, 1985), which was carried out at the Experimental Farm of the State University of Maringá, Paraná, South Brazil. The diets and meat were analyzed at the laboratory of Feed Analyses and Animal Nutrition and Chemistry Laboratory of Food respectively of State University of Maringá.

Thirty three Nellore bulls were used with an initial average age of 27 months old and initial live weight of $402 \mathrm{~kg} \pm 7.58$. Before the experiment, bulls were kept in pasture (Cynodon spp. cv. Tifton 85) without supplementation.

During feedlot the bulls were kept separate in individual pens ( $10 \mathrm{~m}^{2}$ for each animal) and fed twice a day. Bulls had access to the diet formulated by the requirements for fattening beef cattle (NRC, 1996) with a gain of $1.40 \mathrm{~kg} /$ day. The bulls were fed corn silage and water ad libitum and concentrate diet with cracked corn, soybean meal, mineral salt, limestone and urea (Table 1).

The bulls were weighed at the beginning of the experiment. Thereafter, they were weighed every 14 days, observing 16-hours fast, accomplished by removing all feed at $4 \mathrm{p} . \mathrm{m}$. on the day prior to weighing. The total experimental period lasted 84 days, during which the animals reached an average final live weight of $485 \pm 24.9 \mathrm{~kg}$. 
Table 1. Chemical composition of the ingredients and basal diet and percent composition (\%/DM) of the diet.

\begin{tabular}{lccccccccc}
\hline & & \multicolumn{7}{c}{ \% DM } & \\
\cline { 3 - 8 } Ingredients & $\mathbf{D M}^{\mathbf{1}}$ & $\mathbf{C P}^{\mathbf{2}}$ & $\mathbf{O M}^{\mathbf{3}}$ & $\mathbf{E E}^{\mathbf{4}}$ & $\mathbf{N D F}^{\mathbf{5}}$ & $\mathbf{A D F}^{\mathbf{6}}$ & $\mathbf{T C}^{\mathbf{7}}$ & $\mathbf{N F C}^{\mathbf{8}}$ & Diet \% \\
\hline Corn silage & 32.1 & 8.15 & 96.5 & 2.06 & 48.4 & 25.6 & 86.3 & 38.0 & 52.0 \\
Corn cracked & 88.9 & 8.93 & 99.1 & 3.50 & 17.7 & 4.40 & 86.6 & 68.9 & 42.9 \\
Soybean meal & 88.6 & 49.0 & 93.7 & 1.30 & 13.7 & 5.97 & 43.5 & 29.8 & 4.30 \\
Mineral salt & 99.3 & & & & & & & & 0.32 \\
Limestone & 99.3 & & & & & & & & 0.19 \\
Urea & 97.5 & 282 & & & & & & & 0.32 \\
Diet & 41.9 & 11.1 & 97.1 & 2.62 & 33.3 & 15.4 & 83.9 & 50.6 & 100 \\
\hline
\end{tabular}

${ }^{1}$ Dry matter, ${ }^{2}$ Crude protein, ${ }^{3}$ Organic matter, ${ }^{4}$ ether Extract, ${ }^{5}$ Neutral detergent fiber, ${ }^{6}$ Acid detergent fiber, ${ }^{7}$ Total carbohydrates, ${ }^{8}$ Non fiber carbohydrates.

There were three treatments in the experiment: CON - control (11 bulls), MON - monesin (11 bulls) and PRO - propolis extract (11 bulls). The propolis extract LLOS $(\mathrm{C} 1++)$ was prepared according Franco e Bueno (1999). Extracts with alcohol were diluted between 50 to $96^{\circ} \mathrm{GL}$ and with a fix concentration of propolis extract. The extracts were dried using the lyophilization during 24 hours. The samples were stored in closed bottles in a temperature of $-5^{\circ} \mathrm{C}$. It is chartered by intellectual patrimonial by number PI 0605768-3. To prepare the concentrates, the extracts were established in ambient temperature and mixed in soybean and corn to form an addictive that was used to complete the concentrate to the animals. The propolis extract nucleus was developed by Pharmacy Laboratory (UEM - State University of Maringa) according Franco e Bueno (1999).

The product LLOSC $1++$ contains $0.054 \mathrm{mg} / \mathrm{g}$ of total flavonoids in chrysin. Monensin is produced by Elanco ${ }^{\circledR}$.

Monensin and propolis extract nucleus were mixed with concentrate in the same time to feed the animals. These were used $300 \mathrm{mg} / \mathrm{animal} /$ day of monensin and $35 \mathrm{~g} /$ animal/day of propolis extract nucleus.
The chemical composition of silage and concentrate ingredients is presented in Table 1. Dry matter (DM), crude protein (CP), organic matter $(\mathrm{OM})$, mineral matter (MM), ether extract $\mathrm{EE})$, neutral detergent fiber (NDF), acid detergent fiber (ADF) were determined using the method described by Silva and Queiroz (2002). Total carbohydrates (TCH) were determined by equation: $\mathrm{TCH}=100$ $-\mathrm{CP}(\%)+\mathrm{EE}(\%)+\mathrm{MM}(\%)$, described by Sniffen et al. (1992). No fiber carbohydrates (NFC) were obtained by difference between TCH and NDF.

\section{Chemical composition}

The animals were slaughtered at a commercial slaughterhouse $10 \mathrm{~km}$ away from the Maringá, according to industrial practices in Brazil. Following slaughter, the carcasses were identified and chilling for $24 \mathrm{~h}$ at $4{ }^{\circ} \mathrm{C}$. After chilling, the right part of the carcass was used to determine the quantitative characteristics. Twenty-four hours later, Longissimus muscle (LM) samples were taken by a complete cross section between the $12^{\text {th }}$ and $13^{\text {th }}$ ribs. The fat thickness was discarded and the muscle portion was frozen at $-20^{\circ} \mathrm{C}$ for further analyses. 
For analyses the samples were thawed at room temperature $\left(20^{\circ} \mathrm{C}\right)$, grounded (cracker mill), homogenized and analyzed in triplicate.

Meat moisture and ash percentage were determined according to AOAC (CUNNIF, 1998). Crude protein percentage was obtained through the Kjeldahl method (CUNNIF, 1998). Total lipids were extracted through the method Bligh and Dyer (1959) with a chloroform/methanol mixture. Fatty acid methyl esters (FAME) were prepared by triacylglycerol methylation, according to the ISO method (1978).

\section{Cholesterol quantification}

Cholesterol analysis was carried out by method modified by Rowe et al. (1999). A 60\% (w/v) solution of potassium hydroxide was added to the samples in quantities equivalent to $2 \mathrm{~mL} \mathrm{~h}^{-1}$ of sample under 1-h reflux. The residue was dissolved again in $2 \mathrm{~mL}$ hexane containing $0.2 \mathrm{mg} \mathrm{mL}^{-1} 5-\alpha$ cholestane internal standard (IS) (Sigma, USA).

Cholesterol content was analyzed in a 14-A gas chromatograph (Shimadzu, Japan), equipped with a flame ionization detector and fused silica capillary column (25 m long, 0.25-mm internal diameter, and $0.20 \mu \mathrm{m}$ Ohio Valley-30). Injector, column, and detector temperatures were 260, 280, and $280^{\circ} \mathrm{C}$, respectively. Ultra-pure gas fluxes (White Martins) of $1.5 \mathrm{~mL} \mathrm{~min}^{-1} \mathrm{H}_{2}$ as carrier gas,

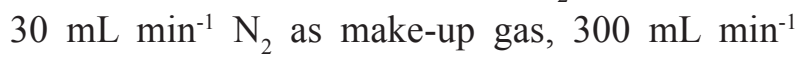
synthetic gas, and $30 \mathrm{~mL} \mathrm{~min}^{-1} \mathrm{~N}_{2}$ for flame were used. The sample injection split mode was: 1:150. Peak integration was carried out with a CG-300 computing integrator (CG Instruments, Brazil) and cholesterol was identified by comparison with standards from Sigma (USA). Sample cholesterol quantification was carried out after verification of method linearity. Standard cholesterol solutions (Sigma, USA) were prepared with concentrations $0.0 ; 0.4 ; 0.8 ; 1.6$, and $2.0 \mathrm{mg} \mathrm{mL}^{-1}$, all containing $0.20 \mathrm{mg} \mathrm{mL}^{-1} 5 \alpha$-cholestane (Sigma, USA) and analyzed. The ratio of the areas of cholesterol and
5- $\alpha$ cholestane was plotted against the cholesterol concentration for injected volumes of $0.0 ; 2.0 ; 3.0$; 4.0, and $5.0 \mu \mathrm{L}$. The curve obtained was used for cholesterol analysis in $\mathrm{mg} 100 \mathrm{~g}^{-1}$.

\section{Analysis of fatty acid methyl esters}

The fatty acids methyl esters (FAMEs) were analyzed in gas chromatograph (Varian, USA) equipped with flame ionization detector and fused silica capillary column CP-7420 (100 m, 0.25 $\mathrm{mm}$ and $0.39 \mu \mathrm{m}$ o.d., Varian, USA) Select Fame. Column temperature was programmed at $165^{\circ} \mathrm{C}$ for $18 \mathrm{~min}, 180^{\circ} \mathrm{C}\left(30^{\circ} \mathrm{C} \mathrm{m^{-1 }}\right)$ for $22 \mathrm{~min}$, and $240^{\circ} \mathrm{C}$ $\left(15^{\circ} \mathrm{C} \mathrm{m^{-1 }}\right)$ for $30 \mathrm{~min}$, with $45-$ psi pressure. The injector and detector were kept at $220^{\circ} \mathrm{C}$ and $245 \mathrm{oC}$, respectively. The gas fluxes (White Martins) used was: $1.4 \mathrm{~mL} \mathrm{~min}^{-1}$ for the carrier gas $\left(\mathrm{H}_{2}\right) ; 30 \mathrm{ml} \mathrm{min}^{-1}$ for the make-up gas $\left(\mathrm{N}_{2}\right)$ and $30 \mathrm{~mL} \mathrm{~min}^{-1}$ and $300 \mathrm{ml} \mathrm{min}^{-1}$ for $\mathrm{H}_{2}$ and the synthetic flame gas, respectively. Sample injection split mode was $1 / 80$. Fatty acids were identified by comparing the relative retention times of FAME peaks of the samples with fatty acids methyl esters standards from Sigma (USA) by spiking samples with standard. The peak areas were determined by Star software (Varian). The data were expressed as percentages of the normalized area of fatty acids.

The areas of peak were determined by software Data Station advanced DataApex Clarity Litr (v.2.4.1.9.1, 2003) the identification of total cholesterol was effectuated by comparison Sigma (EUA).

\section{Experimental design and statistical analysis}

The experimental design consisted of 3 treatments: CON (control), MON (sodium monesin) and PRO (propolis extract). The data were submitted to analysis of variance and the means were compared using Tukey test at 5\% of significance levels, by SAS statistical software (2000). 


\section{Results and Discussion}

\section{Chemical composition}

The addition of additives (sodium monensin and propolis extract) did not influenced $(\mathrm{P}>0.10)$ the chemical composition of Longissimus muscle of bulls (moisture, ash, crude protein, total lipids and total cholesterol) (Table 2).

Table 2. Chemical composition (means) of the Longissimus muscle of Nellore bulls finished in feedlot.

\begin{tabular}{|c|c|c|c|c|c|}
\hline \multirow[b]{2}{*}{ Items } & \multicolumn{4}{|c|}{ Treatments } & \multirow[b]{2}{*}{$\mathbf{P}<\mathbf{F}$} \\
\hline & $\mathrm{CON}^{1}$ & $\mathrm{MON}^{2}$ & PRO $^{3}$ & $\mathrm{SE}^{4}$ & \\
\hline n & 11 & 11 & 11 & & \\
\hline Moisture, $\%$ & 72.0 & 72.8 & 71.3 & 0.87 & NS \\
\hline Ash, $\%$ & 1.07 & 1.08 & 1.10 & 0.02 & NS \\
\hline Crude protein, $\%$ & 24.0 & 23.3 & 23.8 & 0.25 & NS \\
\hline Total lipids, $\%$ & 1.16 & 1.30 & 1.30 & 0.09 & NS \\
\hline Total cholesterol ${ }^{5}$ & 34.3 & 34.7 & 34.2 & 0.32 & NS \\
\hline
\end{tabular}

${ }^{1}$ Control, ${ }^{2}$ Monensin, ${ }^{3}$ Propolis extract, ${ }^{4}$ Standart error, ${ }^{5} \mathrm{mg} / 100 \mathrm{~g}$ of muscle, NS - non - significant.

The percentage of moisture in Longissimus muscle $(72.0 \%)$ was near of the values observed in bulls finished in similar conditions of diet (ABRAHÃO et al., 2005; ROTTA et al., 2009a). Moisture percentage depends of total lipids in Longissimus muscle, because fat is poor in water.

In the same way, ash percentage $(1.10 \%)$ in Longissimus muscle is near of results obtained by some authors (ABRAHÃO et al., 2005; PRADO et al., 2008b; 2008c; 2008d; PRADO et al., 2009a; 2009b; 2009c). Ash percentage change little in function of diets (ROTTA et al., 2009b).

The percentage of crude protein in Longissimus muscle $(23.70 \%)$ was similar to some researches that used bulls finished in feedlot (ARICETTI et al., 2008; PRADO et al., 2008b; 2008c; 2008d). In general, crude protein percentage presents low variation due diet.

Total lipids percentage $(1.20 \%)$ was considered low to bulls finished in feedlot receiving high energy in the diet. This could be explained by the age of these animals (29 months), breed (Bos taurus indicus) and physiological condition (bulls). In general, animals slaughtered younger show less total lipids percentage in Longissimus muscle (PADRE et al., 2006; PADRE et al., 2007; ARICETTI et al., 2008; KAZAMA et al., 2008). In the same way, bulls of zebu breed show low percentage of total lipids in Longissimus muscle in function of less selection to this characteristic (PRADO et al., 2008c). So, bulls finished in pasture system or feedlot show less percentage of total lipids in function of hormonal effects (testosterone) that act to high deposition of muscle tissue (LEE et al., 1990).

The average of total cholesterol for the treatments was $34.4 \mathrm{mg} / 100 \mathrm{~g}$ of muscle. These levels of total cholesterol can be related with the age of slaughter (27 months) and the breed of the animals (Bos taurus indicus). In general, animal slaughtered with 30 months or less show a variation between 30.0 to $45.0 \mathrm{mg} / 100 \mathrm{~g}$ of muscle (ARICETTI et al., 2008; PRADO et al., 2009a; 2009b; ROTTA et al., 2009b).

\section{Fatty acid profile}

The percentage of fatty acid in LM intramuscular 
fat is shown on Table 3. Fatty acid diversity is partly explained by biohydrogenation that occurs in the rumen (TAMMINGA; DOREAU, 1991).
C15:1 n-9, C16:0, C16:1 n-7, C16:1 n-5, C18:0, $\mathrm{C} 22: 0$ and $\mathrm{C} 22: n-3$ (DHA) did not differ $(\mathrm{P}>0.05)$ among treatments.

The percentage of fatty acids C14:0, C14:1 n-7,

Table 3. Fatty acid profile (means) of the Longissimus muscle of Nellore bulls finished in feedlot.

\begin{tabular}{|c|c|c|c|c|c|}
\hline \multirow[t]{2}{*}{ Fatty acids } & \multicolumn{3}{|c|}{ Treatments } & \multirow[b]{2}{*}{$\mathrm{SE}^{4}$} & \multirow[b]{2}{*}{$\mathbf{P}<\mathbf{F}$} \\
\hline & $\mathrm{CON}^{1}$ & $\mathrm{MON}^{2}$ & $\mathrm{PRO}^{3}$ & & \\
\hline $\mathrm{N}$ & 11 & 11 & 11 & & \\
\hline $14: 0$ & 3.02 & 2.96 & 3.23 & 0.14 & NS \\
\hline $14: 1 n-7$ & 0.66 & 0.65 & 0.67 & 0.07 & NS \\
\hline $15: 0$ & $0.32 \mathrm{a}$ & $0.28 \mathrm{ab}$ & $0.26 b$ & 0.01 & 0.03 \\
\hline $15: 1 n-9$ & 0.11 & 0.10 & 0.10 & 0.01 & NS \\
\hline $16: 0$ & 27.9 & 27.8 & 28.6 & 0.39 & NS \\
\hline $16: 1 n-9$ & $0.15 \mathrm{ab}$ & $0.17 \mathrm{a}$ & $0.12 b$ & 0.01 & 0.01 \\
\hline $16: 1 n-7$ & 3.24 & 3.13 & 3.08 & 0.17 & NS \\
\hline $16: 1 n-5$ & 0.41 & 0.40 & 0.37 & 0.01 & NS \\
\hline $17: 0$ & $0.86 \mathrm{a}$ & $0.73 b$ & $0.72 b$ & 0.03 & 0.01 \\
\hline $17: 1 n-9$ & $0.64 a$ & $0.56 b$ & $0.53 b$ & 0.01 & 0.01 \\
\hline 18:0 & 14.2 & 13.8 & 14.6 & 0.58 & NS \\
\hline $18: 1 n-9$ & $40.2 \mathrm{a}$ & $37.0 \mathrm{~b}$ & $39.7 \mathrm{ab}$ & 0.65 & 0.01 \\
\hline $18: 1 n-7$ & $1.06 \mathrm{a}$ & $1.05 \mathrm{a}$ & $0.92 b$ & 0.04 & 0.04 \\
\hline $18: 1 t-11$ & $0.50 \mathrm{a}$ & $0.46 \mathrm{ab}$ & $0.39 b$ & 0.02 & 0.01 \\
\hline $18: 2 n-6$ & $4.21 \mathrm{~b}$ & $6.36 \mathrm{a}$ & $4.30 \mathrm{~b}$ & 0.38 & 0.01 \\
\hline $18: 3 n-6$ & $0.05 \mathrm{~b}$ & $0.08 \mathrm{a}$ & $0.04 \mathrm{~b}$ & 0.01 & 0.01 \\
\hline $18: 2$ cis 9, trans 11 & $0.25 \mathrm{ab}$ & $0.28 \mathrm{a}$ & $0.20 \mathrm{~b}$ & 0.02 & 0.02 \\
\hline $18: 3 n-3$ & $0.43 b$ & $0.57 \mathrm{a}$ & $0.42 b$ & 0.03 & 0.01 \\
\hline $20: 4 n-6$ & $0.99 b$ & $1.45 \mathrm{a}$ & $1.10 \mathrm{~b}$ & 0.10 & 0.01 \\
\hline $20: 5 n-3$ (EPA) & $0.24 b$ & $0.35 \mathrm{a}$ & $0.26 b$ & 0.02 & 0.01 \\
\hline $22: 0$ & 0.05 & 0.24 & 0.05 & 0.10 & NS \\
\hline $22: 5 n-3$ (DPA) & $0.50 \mathrm{~b}$ & $0.73 \mathrm{a}$ & $0.54 \mathrm{~b}$ & 0.05 & 0.01 \\
\hline $22: 6 n-3$ (DHA) & 0.04 & 0.06 & 0.05 & 0.01 & NS \\
\hline
\end{tabular}

${ }^{1}$ Control, ${ }^{2}$ Sodium monensin, ${ }^{3}$ Propolis extract, ${ }^{4}$ Standart error, NS - non - significant.

The percentages of $\mathrm{C} 15: 0(0.32 \%), \mathrm{C} 18: 1$ the percentages of these fatty acids are similar n-9 (40.2\%) and C18:1 t-11 (0.50\%) was to MON treatment $(0.28 ; 37.7$ and $0.46 \%$, higher $(\mathrm{P}<0.03)$ to $\mathrm{CON}$ treatment. However, respectively) in comparison to $\mathrm{PRO}$ treatment 
$(0.26 ; 39.7$ and $0.39 \%$, respectively), but this percentage did not differ between MON and PRO treatments.

The percentage of $\mathrm{C} 16: 1 n-9$ and $\mathrm{C} 18: 2$ cis 9 trans $11(\mathrm{CLA})$ were higher $(\mathrm{P}<0.02)$ to $\mathrm{MON}$ treatment ( 0.17 and $0.28 \%$, respectively) in comparison to PRO treatments $(0.12$ and $0.20 \%$, respectively). However, these fatty acids did not differ between MON and CON (0.15 and 0.25\%) treatments. PRO treatment $(0.12$ and $0.20 \%$, respectively) presented lower $(\mathrm{P}<0.02)$ values to these fatty acids but did not differ between CON.

The percentages of $\mathrm{C} 17: 0$ and $\mathrm{C} 17: 1$ n-9 were higher $(\mathrm{P}<0.01)$ to $\mathrm{CON}$ treatment $(0.86$ and $0.64 \%$, respectively) in comparison with MON (0.73 and $0.56 \%$, respectively) and PRO treatments $(0.72$ and $0.53 \%$, respectively).

The percentage of $\mathrm{C} 18: 1 n-7$ were higher $(\mathrm{P}<0.04)$ in $\mathrm{CON}(1.06 \%)$ and $\mathrm{MON}(1.05 \%)$ treatments, but similar between them. The treatment PRO has the lower $(\mathrm{P}<0.04)$ value for this fatty acid $(0.92 \%)$.

The percentages of C18:3 n-6, C18:3 n-6, C18:3 n-3, C20:4 n-6 and C22:5 n-3 were higher $(\mathrm{P}<0.01)$ to $\mathrm{MON}$ treatment.

The percentage of C20:5 $n-3$ (EPA) were higher $(\mathrm{P}<0.01)$ for MON treatment, but there is no difference between this treatment with PRO treatment.

The higher $(\mathrm{P}<0.08)$ value obtained for $\mathrm{C} 22: 6$ $n$-3 (DHA) was observed for MON treatment, but there is no difference between this treatment with PRO treatment.

As ruminant diets contain low fat concentration, the majority of the adipose tissue is synthesized from lipogenesis. Fatty acids are elongated up to $\mathrm{C} 18: 0$ and are converted into C18:1 by unsaturation (RULE; MACNEIL; SHORT, 1997). As the adipose tissue increases, the deposition of $\mathrm{C} 18: 1$ content also increases and $\mathrm{C} 18: 2$ is reduced.

Oleic acid (C18:1) increases human HDLCholesterol (High Density Lipoprotein) and decreases LDL-cholesterol (Low Density Lipoprotein) concentration in blood (KATAN; ZOCK; MENSINK, 1994). Studies demonstrated a strong relationship between LDL-cholesterol levels and human cardiovascular diseases, and that HDL-cholesterol has an inverse relation with the risk of cardiovascular diseases (KWITEROVICH, 1997).

Saturated fatty acid (SFA) did not have difference $(\mathrm{P}>0.10)$ among treatments (Table 4). The average for this parameter was $46.5 \%$. SFA is present in meat in high concentration due biohydrogenation that occur in rumen that change the double bonds of unsaturated fatty acids.

Monounsaturated fatty acids (MUFA) have difference $(\mathrm{P}<0.01)$ among treatments. The higher value was observed in $\mathrm{CON}$ treatment $(47.0 \%)$.

There was difference $(\mathrm{P}<0.01)$ among treatments for polyunsaturated fatty acids (PUFA). Animals of MON (9.92\%) treatment obtained higher $(\mathrm{P}<0.01)$ value for this characteristic. CON (6.74\%) and PRO (6.93\%) have lower values for PUFA. The percentage of PUFA was lower $(\mathrm{P}<0.01)$ than SFA and MUFA due the biohidrogenation in rumen, that transform PUFA in MUFA or SFA (TAMMINGA; DOREAU, 1991).

$n$-3 was higher $(\mathrm{P}<0.01)$ in $\mathrm{MON}$ treatment $(1.73 \%)$ in comparison with $\mathrm{CON}(1.22 \%)$ and PRO $(1.27 \%)$. The percentage of this class of fatty acids was low in relation with $n-6$. This is because the predominant polyunsaturated fatty acid in meat is C18:2 n-6 that appear in high concentration in comparison with $\mathrm{C} 18: 3$ n-3. 
Table 4. Proportion (\%) (means) of saturated fatty acids (SFA), monounsaturated fatty acids (MUFA), polyunsaturated fatty (PUFA), fatty acids $n-6$, fatty acids $n-3$, PUFA/SFA and $n-6 / n-3$ ratio of the Longissimus muscle of Nellore bulls finished in feedlot.

\begin{tabular}{lccccc}
\hline Fatty acids & \multicolumn{3}{c}{ Treatments } & & \\
\cline { 2 - 4 } & $\mathbf{C O N}^{1}$ & $\mathbf{M O N}^{2}$ & $\mathbf{P R O}^{\mathbf{3}}$ & $\mathbf{S E}^{4}$ & $\mathbf{P}<\mathbf{F}$ \\
\hline $\mathrm{n}$ & 11 & 11 & 11 & & \\
\hline SFA & 46.3 & 45.9 & 47.4 & 0.76 & $\mathrm{NS}$ \\
MUFA & $47.0 \mathrm{a}$ & $44.2 \mathrm{~b}$ & $45.9 \mathrm{~b}$ & 0.81 & 0.01 \\
PUFA & $6.74 \mathrm{~b}$ & $9.92 \mathrm{a}$ & $6.93 \mathrm{~b}$ & 0.57 & 0.01 \\
$n-3$ & $1.22 \mathrm{~b}$ & $1.73 \mathrm{a}$ & $1.27 \mathrm{~b}$ & 0.11 & 0.01 \\
$n-6$ & $5.26 \mathrm{~b}$ & $7.90 \mathrm{a}$ & $5.44 \mathrm{~b}$ & 0.47 & 0.01 \\
PUFA/SFA & $0.14 \mathrm{~b}$ & $0.22 \mathrm{a}$ & $0.15 \mathrm{~b}$ & 0.01 & 0.01 \\
$n-6 / n-3$ & 4.32 & 4.63 & 4.33 & 0.17 & $\mathrm{NS}$ \\
\hline
\end{tabular}

${ }^{1}$ Control, ${ }^{2}$ Sodium monensin, ${ }^{3}$ Propolis extract, ${ }^{4}$ Standart error, NS - non - significant.

MON treatment $(7.90 \%)$ presented higher $(\mathrm{P}<0.01)$ values of $n-6$. CON $(5.26 \%)$ and PRO $(5.44 \%)$ had lower $(\mathrm{P}<0.01)$ values for this parameter. This shows that animals fed with addition of sodium monensin in diet had higher values for essential fatty acids that $\mathrm{CON}$ and PRO treatments.

PUFA/SFA ratio was higher $(\mathrm{P}<0.01)$ for $\mathrm{MON}$ treatment $(0.22 \%)$ in comparison with $\mathrm{CON}(0.14 \%)$ and PRO $(0.15 \%)$. However, no treatment has recommended values for this ratio, that should be 0.40 or higher values. PUFA/SFA ideal ratio plays important roles in reducing the risk of coronary heart disease; however, the optimal balance between these two classes of fatty acids is still a matter of debate (HU, 2001).

No difference $(\mathrm{P}>0.10)$ was observed for $n-6 / n-3$ ratio among different treatments. This ratio must be inferior to 4 (ENGLAND, 1994). In this study, the average found for $n-6 / n-3$ was 4.44 , so this value is close that recommended by English Department of Health (1994).

\section{Conclusions}

The addition of sodium monensin or propolis extract did not alter the chemical composition of Longissimus muscle of bulls finished in feedlot. However, the fatty acid profile is changed by addition of sodium monensin or propolis extract in the diets. Essential fatty acids (C18:2 n-6 and C18:3 $n-3)$ are found in more concentration in Longissimus muscle of animals that received sodium monensin. The meat of animals fed with addition of sodium monensin is better in relation of fatty acid profile in comparison with control and propolis extract treatment. However, with the prohibition of monensin sodium in animal feed, propolis extract can be an alternative because did not damage the meat quality in comparison with control treatment and could reduce the greenhouse effect.

\section{References}

ABRAHÃO, J. J. S.; PRADO, I. N.; PEROTTO, D.; MOLETTA, J. L. Effects of replacing corn with increasing levels of cassava starch by-products on carcass characteristics and meat for young bulls. Brazilian Journal of Animal Science, Viçosa, v. 34, n. 5, p. 16401650, 2005.

ARICETTI, J. A.; ROTTA, P. P.; PRADO, R. M.; PEROTTO, D.; MOLETTA, J. L.; MATSUSHITA, M.; PRADO, I. N. Carcass characteristics, chemical 
composition and fatty acid profile of Longissimus muscle of bulls and steers finished in a pasture system. Asian Australasian Journal of Animal Science, Seoul, v. 21, n. 10, p. 1441-1448. 2008.

BLIGH, E. G.; DYER, W. J. A rapid method of total lipid extraction and purification. Canadian Journal Biochemistry and Physiology, Ottawa, v. 37, n. 8, p. 911917, 1959.

CIOMS/OMS. Council for International Organizations of Medical Services. WHO distribution and sales service, 1211 Geneva 27, Switzerland, International Guiding Principles for Biomedical Research Involving Animals, 1985.

CUNNIF, P. A. Official methods of analysis of AOAC international. $6^{\text {th }}$ ed. Arlington: Association of Official Analytical Chemists, 1998.

DUCATTI, T.; PRADO, I. N.; ROTTA, P. P.; PRADO, R. M.; PEROTTO, D.; MAGGIONI, D; VISENTAINER, J. V. Chemical composition and fatty acid profile in crossbred (Bos taurus $x$ Bos indicus) young bulls finished in feedlot. Asian-Australasian Journal Animal Science, Seoul, v. 22, n. 3, p. 433-439, 2009.

DUFFIELD, F. T.; BAGG, R. N. Use of ionophores in lactating dairy cattle: a review. Canadian Veterinary Journal, Ottawa, v. 41, n. 5, p. 388-394, 2000.

ENGLAND. Department of Health. Nutritional aspects of cardiovascular disease. London: HMSO, 1994. p. 3746. (Report on Health and Social Subjects, 46).

FRANCO, S. L.; BUENO, J. H. F. Otimização de processo extrativo de própolis. Infarma, Londrina, v. 11, n. 11/12, p. 48-51. 1999.

HU, F. B. The balance between $\omega-6$ and $\omega-3$ fatty acids and the risk of coronary heart disease. Nutrition, Boston, v. 17, n. 9, p. 741-742, 2001.

INTERNATIONAL ORGANIZATION FOR STANDARDIZATION - ISO. Animal and vegetable fats and oils - preparation of methyl esters of fatty acids, ISO 5509. Geneva, 1978. p. 01-06.

KATAN, M. B.; ZOCK, P. L.; MENSINK, R. P. Effects of fats and fatty acid on blood lipids in humans: on review. American Journal of Clinical Nutrition, Bethesda, v. 60, p. 1017-1022. 1994. Suplemento 1.

KAZAMA, R.; ZEOULA, L. M.; PRADO, I. N.; SILVA, D. C.; DUCATTI, T.; MATSUSHITA, M. Quantitative and qualitative carcass characteristics of heifers fed different energy sources on a cottonseed hulls and soybean hulls based diet. Brazilian Journal of Animal Science, Viçosa, v. 37, n. 2, p. 350-357, 2008.
KWITEROVICH, P. O. The effect of dietary fat, antioxidants, and pro-oxidants on low lipids, lipoproteins and atherosclerosis. Journal of American Dietetic Association, Chicago, v. 97, n. 7, p. 31-41. 1997.

LEE, C. Y.; HENRICKS, D. M.; SKELlEY, G. C.; GRIMES, L. W. Growth and hormonal response of intact and castrate male cattle to trenbolone acetate and estradiol. Journal of Animal Science, Savoy, v. 68, n. 9, p. 2682-2689, 1990.

MACEDO, L. M.; PRADO, I. M.; PRADO, J. M.; ROTTA, P. P.; PRADO, R. M.; SOUZA, N. E.; PRADO, I. N. Chemical composition and fatty acids profile of five carcass cuts of crossbred heifers finished in feedlot. Semina:Ciências Agrárias, Londrina, v. 29, n. 3, p. 599$610,2008$.

MAGGIONI, D.; MARQUES, J. A.; PEROTTO, D.; ROTTA, P. P.; DUCATTI, T.; MATSUSHITA, M.; SILVA, R. R.; PRADO, I. N. Bermuda grass hay or sorghum silage with or without yeast addition on performance and carcass characteristics of crossbred young bulls finished in feedlot. Asian Australasian Journal of Animal Science, Seoul, v. 22, n. 2, p. 206-215, 2009.

MARCUCCI, M. C. Propolis chemical composition, biological properties and therapeutic activity. Apidologie, Les Ulis, v. 26, n. 2, p. 83-99, 1995.

MOREIRA, F. B.; SOUZA, N. E.; MATSUSHITA, M.; PRADO, I. N.; NASCIMENTO, W. G. Evaluation of carcass characteristics and meat chemical composition of Bos indicus $x$ Bos taurus crossbred steers finished in pasture systems. Brazilian Archives of Biology and Technology. Curitiba, v. 46, n. 4, p. 609-616, 2003.

NATIONAL RESEARCH COUNCIL - NRC. Nutrient requirements of beef cattle. $6^{\text {th }}$ ed. Washington, D.C.: National Academy Press, 1996. 242 p.

OLIVEIRA, J. S.; QUEIROZ, A. C.; LANA, R. P.; MANTOVANI, H. C.; GENEROSO, R. A. R. Effects of monensin and bee propolis on in vitro fermentation of amino acids by mixed ruminal bacteria. Brazilian Journal of Animal Science, Viçosa, v. 35, n. 1, p. $275-$ 281, 2006.

PADRE, R. G.; ARICETTI, J. A.; GOMES, S. T. M.; GOES, R. H. T. B.; MOREIRA, F. B.; PRADO, I. N.; VISENTAINER, J. V.; SOUZA, N. E.; MATSUSHITA, M. Analysis of fatty acids in Longissimus muscle of steers of different genetic breeds finished in pasture systems. Livestock Science, Amsterdam, v. 110, n. 1, p. 57-63, 2007.

PADRE, R. G.; ARICETTI, J. A.; MOREIRA, F. B.; MIZUBUTI, I. Y.; PRADO, I. N.; VISENTAINER, J. V.; SOUZA, N. E.; MATSUSHITA, M. Fatty acids profile 
and chemical composition of Longissimus muscle of bovine steers and bulls finished in pasture system. Meat Science, Amsterdam, v. 74, n. 1, p. 242-248, 2006.

PRADO, I. N.; ARICETTI, J. A.; ROTTA, P. P.; PRADO, R. M.; PEROTTO, D.; VISENTAINER, J. V.; MATSUSHITA, M. Carcass characteristics, chemical composition and fatty acid profile of the Longissimus muscle of bulls (Bos taurus indicus x Bos taurus taurus) finished in pasture systems. Asian Australasian Journal of Animal Science, Seoul, v. 21, n. 10, p. 1449-1457, 2008d.

PRADO, I. N.; ITO, R. H.; PRADO, J. M.; PRADO, I. M.; ROTTA, P. P.; MATSUSHITA, M.; VISENTAINER, J. V.; SILVA, R. R. The influence of dietary soyabean and linseed on the chemical composition and fatty acid profile of the Longissimus muscle of feedlot-finished bulls. Journal of Animal Feed Science, Jablonna, v. 17, n. 3, p. 307-317, 2008a.

PRADO, I. N.; OLIVEIRA, A. N.; ROTTA, P. P.; PEROTTO, D.; PRADO, R. M.; SILVA, R. R.; SOUZA, N. E.; MOLETTA, J. L. Chemical and fatty acid composition of Longissimus muscle of crossbred bulls finished in feedlot. Asian Australasian Journal of Animal Science, Seoul, v. 22, n. 7, p. 1054-1059, 2009c.

PRADO, I. N.; PRADO, R. M.; ROTTA, P. P.; VISENTAINER, J. V.; MOLETTA, J. L; PEROTTO, D. Carcass characteristics and chemical composition of the Longissimus muscle of crossbred bulls (Bos taurus indicus vs Bos taurus taurus) finished in feedlot. Journal of Animal Feed Science, Jablonna, v. 17, n. 3, p. 295-306, 2008b.

PRADO, I. N.; ROTTA, P. P.; PRADO, R. M.; VISENTAINER, J. V.; MOLETTA, J. L.; PEROTTO, D. Carcass characteristics and chemical composition of the Longissimus muscle of Purunã and $1 / 2$ Purunã x $1 / 2$ Canchin bulls. Asian Australasian Journal of Animal Science, Seoul, v. 21, n. 9, p. 1296-1302, 2008c.

PRADO, J. M.; PRADO, I. N.; VISENTAINER, J. V.; ROTTA, P. P.; PEROTTO, D.; MOLETTA, J. L.; PRADO, I. M.; DUCATTI, T. The effect of breed on chemical composition and fatty acid composition on Longissimus dorsi muscle of Brazilian beef cattle. Journal of Animal Feed Science, Jablonna, v. 18, n. 2, p. 231-240, 2009a.

PRADO, R. M.; PRADO, I. N.; MARQUES, J. A.; ROTTA, P. P.; VISENTAINER, J. V.; SILVA, R. R.; SOUZA, N. E. Meat quality of the Longissimus muscle of bulls and steers (1/2 Nellore vs. $1 / 2$ Simenthal) finished in feedlot. Journal of Animal and Feed Science, Jablonna, v. 18 , n. 2, p. 221-230, 2009b.

ROTTA, P.P.; PRADO, I.N.; PRADO, R. M.; MOLETTA,
J. L.; SILVA, R. R.; PEROTTO, D. Carcass characteristics and chemical composition of the Longissimus muscle of Nellore, Caracu and Holstein-friesian bulls finished in feedlot. Asian Australasian Journal of Animal Science, Seoul, v. 22, n. 4, p. 598-604, 2009a.

ROTTA, P. P.; PRADO, R. M.; PRADO, I. N.; VALERO, M. V.; VISENATINER, J. V.; SILVA, R. R. The effects of genetic groups, nutrition, finishing systems and gender of Brazilian cattle on carcass characteristics and beef composition and appearance: a review. Asian Australasian Journal of Animal Science, Seoul, v. 22, n. 2, 1718-1734, 2009b.

ROWE, A.; MACEDO, F. A. F.; VISENTAINER, J. V.; SOUZA, N. E.; MATSUSHITA, M. Muscle composition and fatty acid profile in lambs fattened in dry-lot or pasture. Meat Science, Amsterdam, v. 51, n. 4, p. 283$288,1999$.

RULE, D. C.; MACNEIL, M. D.; SHORT, R. E. Influence of sire growth potential, time on feed, and growing finishing strategy on cholesterol and fatty acids of ground carcass and Longissimus muscle of beef steers. Journal of Animal Science, Savoy, v. 75, n. 6, p. 1525-1533, 1997.

SAS Institute. SAS/STAT ${ }^{\circledR}$. User's guide: statistics. Version 8.1. 4. ed. Cary: SAS Institute, 2000. v. 2.

SILVA, D. J.; QUEIROZ, A. C. Análise de alimentos: métodos químicos e biológicos. Viçosa: Universidade Federal de Viçosa, 2002. 235 p.

SNIFFEN, C. J.; O'CONNOR, J. D. O.; Van SOEST, P. J.; FOX, D. G.; RUSSEL, J. B. A net carbohydrate and protein system for evaluating cattle diets: IICarbohydrate and protein availability. Journal of Dairy Science, Savoy, v. 70, n. 11, p. 3562-3577. 1992.

TAMMINGA, S.; DOREAU, M. Lipids and rumen digestion. In: HOUANY, J. P. (Ed.). Rumen microbial metabolism and ruminant digestion. Paris: INRA, 1991. p. 151-164.

WEBB, E. C.; O'NEIL, H. A. The animal fat paradox and meat quality. Meat Science, Amsterdam, v. 80, n. 1, p. 28-36, 2008.

WOOD, J. D.; RICHARDSON, R. I.; NUTE, G. R.; FISHER, A. V.; CAMPO, M. M.; KASAPIDOU, E.; SHEARD, P. R.; ENSER, M. Effects of fatty acids on meat quality: a review. Meat Science, Amsterdam. v. 66, n. 1, p. 21-32. 2004. 